\title{
Shifting Trade Matrix in Turbulent World Order ${ }^{1}$
}

\author{
A. Mukhopadhyay
}

Abhijit Mukhopadhyay - Senior Fellow (Economy and Growth), Observer Research Foundation; 20 Rouse Avenue, New Delhi, 110002, India; E-mail: a.mukhopadhyay@orfonline.org

\begin{abstract}
The international trade order has entered a turbulent phase with the deepening of trade wars across the globe. What looks like chaotic, inward-looking policymaking on the surface is actually a battle for trade and technology supremacy between the U.S. and China. The slow but gradual shift of international trade and business toward Asia and away from the North Atlantic and Western Europe provides the backdrop of this conflict. A shift from developed to developing countries has also started to appear. In that sense, the battle for supremacy was bound to happen, as China played the principal role in that shift.

In the process, the "golden era of trade" signified by the rise of the World Trade Organization (WTO) has been halted while multilateralism in trade is almost non-existent. Fast growing economies, including the emerging ones, are going to bear most of the brunt of this trade slowdown.

Two principal protagonists of this epic battle, China and the U.S., are looking for alternative sources of economic prosperities in their own ways. In the absence of multilateral platforms for trade, the action plan for developing nations is getting clearer by the day. These countries have to scout for trade alliances where each can benefit economically. To do so, each of these countries has to analyze its economy and then seek out trade partners accordingly. Unpreparedness to deal with this trade turmoil may have disastrous consequences for these countries.
\end{abstract}

Key words: trade war; WTO; international trade; multilateralism; regional cooperation

For citation: Mukhopadhyay A. (2019) Shifting Trade Matrix in Turbulent World Order. International Organisations Research Journal, vol. 14, no 4, pp. 89-111 (in English). DOI: 10.17323/1996-7845-201904-05.

\section{Background}

The year 2018 turned out to be a watershed in the recent history of world trade and development. In early 2018, the U.S. administration announced various unilateral tariff measures that triggered what by now most are calling a "trade war." It began with quotas and tariffs on solar panels and washing machine imports from China, and later moved to the imposition of tariffs on products like steel and aluminium which affected a wider set of countries. The trigger for the trade war was thus pulled, and since then the war has continued unabated.

On the U.S. side, these tariffs were imposed by invoking a World Trade Organization (WTO) clause related to imports that could threaten "national security." However, the

\footnotetext{
${ }^{1}$ The editorial board received the article in September 2019.
} 
actual idea has been to curb competition from "cheap metal that is subsidised by foreign countries" - amounting to a dumping allegation [UNCTAD, 2018].

On 14 August 2017, the U.S. president's office nudged the U.S. Trade Representative (USTR) office to investigate China under Section 301 of the Trade Act 1974. Four specific elements of China's technology transfer regime were under the scrutiny: the Chinese government's use of opaque and discretionary administrative processes, joint venture (JV) requirements, foreign equity limitations, procurements and other mechanisms to pressure the transfer of U.S. technology and intellectual property (IP) to China; acts, policies and practices by the Chinese government that impede the ability of American companies in setting market-based terms in technology-related negotiations; governmental direction and unfair facilitation of outbound Chinese investments targeting American companies and assets in key industrial sectors; and the Chinese government's support of unauthorized intrusions into U.S. commercial networks or cyber-enabled theft of trade secrets and other proprietary information [USTR, 2018].

The investigation covered wide-ranging sectors including oil and natural gas, automobile, nuclear power, telecom, banking, biotechnology, aviation, information technology (IT), integrated circuits (ICs), industrial machinery and robotics, steel and other metals, and renewable energy. Therefore, the preparation to implicate China on trade issues has been going on for quite some time and, as already noted, the principal reason cited revolved around "national security and safety."

In early March 2018, the U.S. raised tariffs on $\$ 92$ billion worth of imports covering steel and aluminium products, washing machines, solar panels and a range of other products in which China holds substantial export shares in the United States. Apart from China, countries affected by this set of tariffs included Brazil, Korea, Argentina, India and the EU. The second dimension, unveiled late in March 2018, was the American president's directive to the USTR to take all possible actions against China, including using penal tariffs on its exports, for "harming American intellectual property rights, innovation, or technology development" [Dhar, 2018].

By August 2018 the U.S. had brought in a $25 \%$ tax on a second tranche of goods worth $\$ 16$ billion. These goods included motorcycles, aerials and optical fibres [BBC News, 2018]. These measures were interpreted as part of the American president's broader "America First" approach. In natural reaction, all affected countries retaliated with counter tariffs. The EU announced "rebalancing measures" targeting 340 American export items valued at $\$ 7.2$ billion, roughly equal to the amount of its steel and aluminium exports adversely affected by the U.S. tariff. Canada announced retaliatory tariffs of up to $25 \%$ on U.S. imports of steel and aluminium, orange juice, whiskey and other food products having a value of around CDN \$16.6 billion, equal to the value of targeted Canadian steel exports to the United States. Mexico announced similar measures on a number of products, including dairy, horticulture and meat products "up to an amount comparable to the damage caused by the U.S. action" [Dhar, 2018].

In early April 2018, China decided to retaliate against the U.S. by imposing tariffs on 128 products which accounted for $\$ 3$ billion in exports to China in 2017. China proposed the imposition of a $15 \%$ tariff on the first set of products, including fresh 
fruits, dried fruits and nuts, wines, modified ethanol, American ginseng and seamless steel pipes. On a second set of products, including pork, pork products and recycled aluminium, a $25 \%$ tariff was proposed. Continuing the tit-for-tat policy, China further decided to impose additional tariffs of $25 \%$ on chemical products, medical equipment and energy imported from the U.S. [Dhar, 2018].

On 8 August 2018 the Chinese government signalled its willingness to impose retaliatory tariffs on certain U.S. goods just ahead of a gathering of China's top leaders for their annual summit. This was reportedly in retaliation to the "Trump administration's publishing a list of Chinese products that will confront $25 \%$ duties starting on 23 August 2018 " which would raise the value of tariffs to $\$ 50$ billion, up from the $\$ 34$ billion. This willingness later translated into additional tariffs on imports from the U.S worth $\$ 60$ billion. The Customs Tariff Commission of the State Council unveiled lists of 5,207 American products which would face additional tariffs of $5 \%$ to $25 \%$. The effect of this set of tariffs could be quite significant in the near future [Chakraborty, 2018]. ${ }^{2}$

The U.S. government again hit China with a new set of tariffs affecting $\$ 200$ billion worth of Chinese goods from the middle of September 2018. Unlike the previous set of tariffs mainly aimed at capital goods, this new tariff would hit thousands of consumer goods made in China, ranging from luggage and electronics to housewares and foods. The imposition of tariffs is expected ultimately to result in an increase in the costs and prices of these goods [Partington, Rushe, 2018].

This action apparently had been undertaken by the U.S. to challenge China's indifference to addressing its "unfair policies and practices. China deeply regretted the decision and conveyed that it has "no choice but to take countermeasures.

Much to the relief of many countries, on 1 December 2018 the standstill agreement reached between the U.S. and China at the sidelines of the Group of 20 (G20) meetings had created a much-needed breather for these two countries and rest of the world. Both countries agreed not to impose tariffs for the next 90 days. However, this temporary truce has proven to be inadequate to resolve the deeper trade problems in their relationship, and seems to have been a short-term political agreement rather than a substantive step toward resolution of existing problems.

Multiple rounds of talks between these two countries failed to end the deadlock, and the war is expected to continue. In addition, the situation worsened in the interim period as the U.S. stepped up its efforts to ban the Chinese tech company Huawei from doing any business with American companies. The U.S. federal government's decision to expand official ties with Taiwan is expected to further aggravate the situation.

This article offers a diagnostic study of the current trade turmoil in the world. Though the dominant discussions are focused on the U.S.-China standoff, there is a need to see these trade tensions from the perspective of the developing and emerging economies. This paper analyzes the U.S.-China trade war in that context. It first describes and provides critique of the economics behind American trade protectionism, and then goes deeper into the reason behind the Sino-American tussle - that is, the

${ }^{2}$ The WTO has warned that U.S.-China trade tensions are expected to have ripple effects across the world. 
distinct shift in world trade momentum toward Asia, led by a flourishing China, in the last two decades or so. The article then delves into the slowdown in world trade and economic growth which resulted from such trade protectionisms.

As a multilateral oversight agency, the WTO could have played a measured role in easing these tensions. However, on the contrary, the WTO has taken lopsided positions which continue to favour the developed first world countries. This article critically looks at the WTO's role and American influence in the WTO to subvert the existing dispute settlement mechanism. Instead of playing the role of a good referee, the WTO is implicitly providing justification for the U.S.'s unilateral trade restrictions. The article concludes with the argument that stronger cooperation among developing nations outside the WTO framework is imperative for these economies to survive the shifting global trade matrix.

This article builds on the theorization of gains from international trade, but focuses more on happenings in international trade and business in the last two years. Mostly analyzing current affairs in global trade, the paper provides a critique of the unilateralism that has been observed lately in international trade. It is also a critical reflection on the stance of the WTO as a multilateral trade platform; the paper ends with consideration of the strategic direction for the developing countries toward deeper cooperation.

\section{The Economics Behind the American Protectionist Stance}

A simple rationale provided for the imposition of tariffs, particularly in the U.S., revolves around domestic job protection. An "America First" approach entails cutting down imports so that domestic producers can sell their goods. In turn, more employment will be generated (for American people) within the economy. Moves to reduce the volume of imports and to make immigration policy more strict therefore enjoy a substantial amount of popular support among Americans who have, in the last few decades, witnessed the outsourcing of U.S. jobs to other countries where labour is cheaper. The number of immigrant workers, particularly in high-tech sectors, has also increased in the U.S. in the last few decades. Ever-increasing U.S. trade deficit figures further fuel this sentiment. That is why protecting jobs by cutting down trade deficits (by sizeable reductions in imports) has enjoyed such popularity in the United States. In a similar way, targeting China for cutting imports by the imposition of tariffs also finds substantial popular mass support [Mukhopadhyay, 2018a].

As evident from Fig. 1, the U.S. deficit in the trade of goods has been increasing since the 1980s. After a mild improvement in the early 1990s, it deteriorated after the mid-1990s. After the early 2000s trade deficits started rising rapidly, which coincides with China's accession to WTO and its subsequent entry into the U.S. market. And here probably lies the popular justification given by the U.S. government citing the "China factor" for its worsening trade deficit figures.

But, the most important point to note is that the U.S. trade in goods deficit with the rest of the world also kept on increasing over this period of time. Though trade in services since the late 1980s generated a surplus and has continued to increase, that 


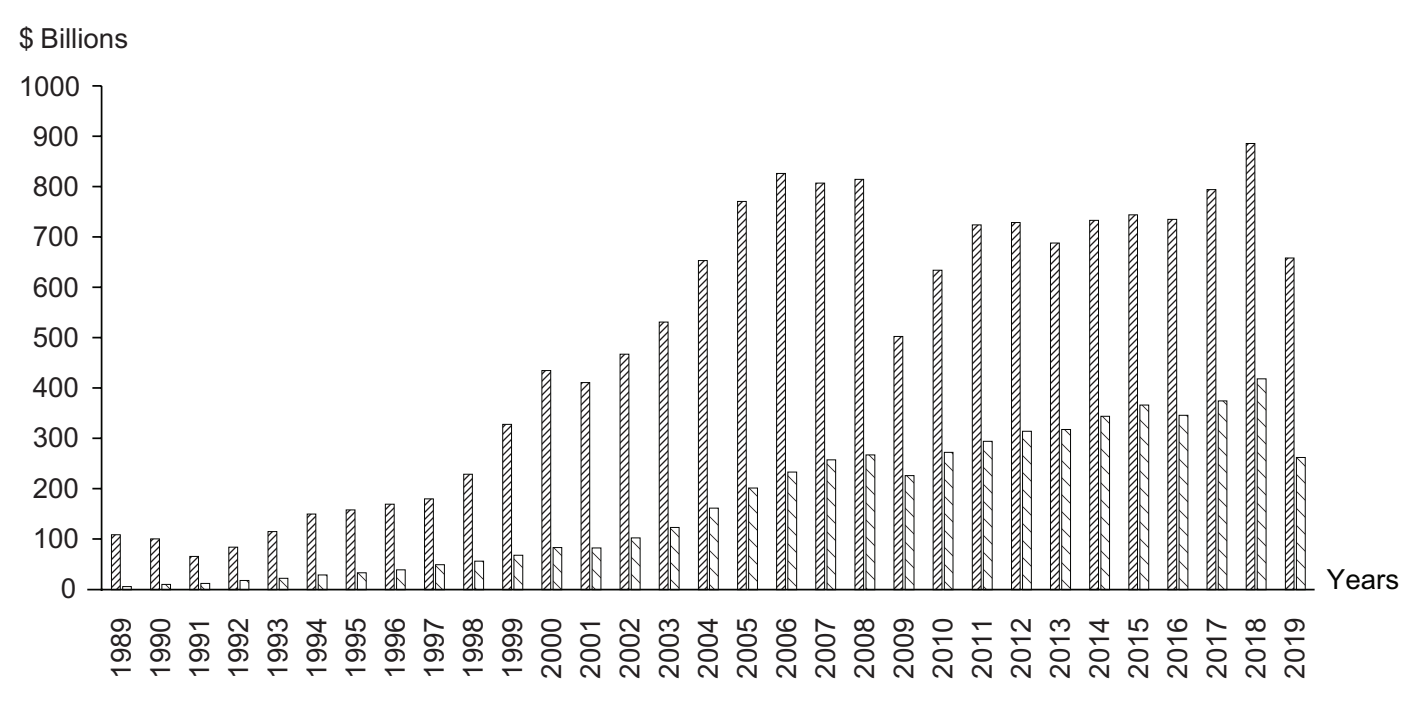

World $\square$ China

Fig. 1. Trends in U.S. Trade Deficits in Goods With China and the World (\$ Billions)

* U.S. trade deficit figures with the world include deficits with China.

* 2019 figures are up to September.

* Seasonally adjusted figures of exports and imports of the U.S. are taken to calculate trade deficits.

Source: [United States Census Bureau, U.S. Department of Commerce].

surplus has been grossly inadequate to offset the rapidly deteriorating trade in goods imbalance.

Based on deficit figures from 2017, the U.S. trade deficit with China stood at $\$ 375.6$ billion and its trade deficit with the entire world was at $\$ 795.7$ billion. That simply means that the U.S. had a trade deficit of $\$ 420.1$ billion with rest of the world; even if China was completely pushed out of the American market, the U.S. economy would have to deal with a huge goods trade deficit and an overall current account deficit. This points toward a general systemic flaw which is beyond the so-called "China factor."

In terms of national income identity, the gap between the exports and imports of any country is equal to the savings-investment gap. ${ }^{3}$ America, being a consumption-led economy, for years saved at a very low rate. Its domestic savings rate has not reached $24 \%$ since the $1950 \mathrm{~s}$, and in more recent years it has gone below $17 \%$. This implies that the economy in general spent more than it saved (and invested), and that consumer spending (and investment) was supported by borrowing [Dhar, 2018; Dutt, 2006; Guttman, Plihon, 2008; Montgomerie, 2007].

${ }^{3}$ National income identity is given as: $Y=C+I+G+(X-M)$ [where $Y, C, I, G, X$ and $M$ are national income (output), consumption, investment, government expenditure, export and import respectively].

Assuming government intervention at zero level, the identity can be reduced to: $S-I=X-M$, where $S$ is savings $=(Y-C)$.

Therefore, trade deficit (or surplus) is equal to the savings-investment gap (or surplus savings over investment). 
In other words, the economy grew with consumption as its main driver, but consumption was generated mainly by borrowing. This spend-thrift way to prosperity worked absolutely fine as long as the country could successfully borrow from global capital markets and its own globalized financial architecture. But that borrowing-driven party ended with the 2008 financial crisis as capital markets everywhere became stressed, and financing the trade deficit became increasingly more difficult. Therefore, the real macroeconomic problem facing the U.S. is systemic and broadly due to its consumption-driven growth model [Dhar, 2018; Montgomerie, 2007].

Carrying on with the overtly populist agenda and appeasing the domestic constituency requires these unilateral tariff measures and trade barriers to shift the focus away from the origin of the economic problem - and until now it has.

In short, unilateral protectionist actions by the U.S. may or may not help strengthen its domestic producers and employment figures, but those are unlikely to make a significant difference to the size of its external deficit given the economic model the economy is pursuing [Ciuriak, 2018]. Rather, those measures are likely to introduce disruptions to trade patterns and add to the uncertainty both domestically and internationally [Grennes, 2017]. If that happens, world trade will suffer badly.

\section{The Shift in Economic and Trade Momentum Toward Asia and China}

The growing influence of China is one of the implicit reasons for its ongoing conflict with the United States. Official explanations may point to different reasons, but at a broad level it looks like a battle for supremacy in international business.

Technological supremacy also plays a role in this conflict between the world's two largest economies. China grew phenomenally in the last 20 years or so and the gap between China's and the U.S.'s nominal GDP (gross domestic product) has narrowed in recent times.

More than the spectacular rise in nominal GDP, China's influence has grown in international trade. The Chinese success story, in fact, is firmly rooted in its exportoriented economic growth model. It is not an overstatement to say that China's rising economic influence would have triggered a struggle with the U.S. for global economic and technological supremacy one day or another. It is happening now.

Examination of the volumes and direction of trade in the last 30 years shows that the major direction of trade was concentrated toward North America and Europe [Krugman, Obstfeld, 2009]. This started to shift after China's accession to the WTO in 2001. A prolonged debate among the leading developed countries preceded the accession, but China rapidly made giant strides in international trade, particularly exports. A goods export-oriented strategy made Chinese GDP grow in tandem. According to World Economic Forum data, China's GDP exceeded \$14 trillion in 2018. The gap between China, the second-largest global economy, and the U.S., the largest economy at \$20.4 trillion, narrowed considerably over a period of approximately 17 years. 
If we look into the trends in world merchandise trade volume growth by region in recent years (Fig. 2), this shift toward Asia is quite evident.

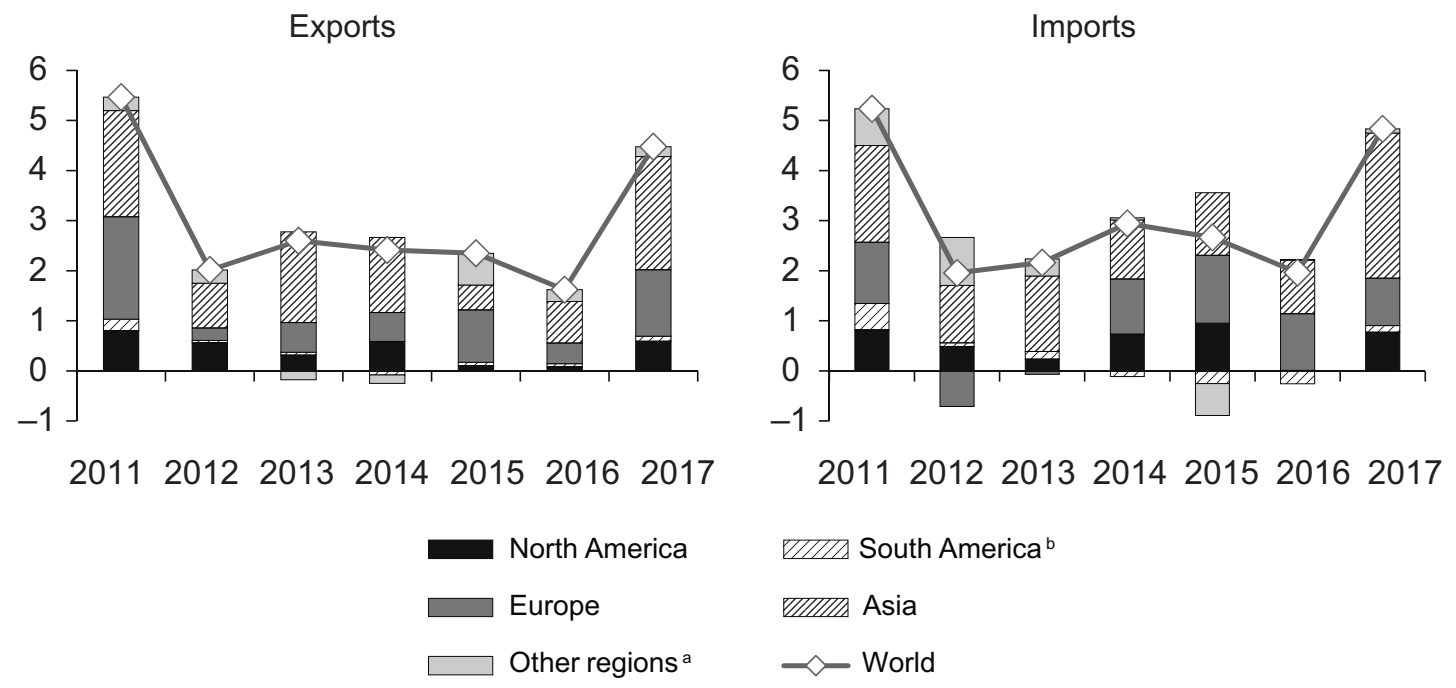

Fig. 2. Contributions to World Merchandise Trade Volume Growth by Region, 2011-17

${ }^{a}$ Refers to South and Central America and the Caribbean.

${ }^{\mathrm{b}}$ Other regions include Africa, the Middle East and the Commonwealth of Independent States (CIS), including associate and former member states.

Source: [WTO, 2018].

The contribution of different regions in world trade volume growth from 2011-17 confirms this trend. Both in terms of exports and imports, growth was largely driven by Asia. And, in that Asian growth story, China played a significant role.

Fig. 3 depicts trends in the volume index of exports and imports in these regions. The base of the indices is the first quarter of 2012. These trends reaffirm the shift of international trade to Asian regions. With trade volumes fluctuating in South America and Europe, the fight for trade supremacy is clearly now between North America and Asia. Export volumes are driven by Asia while import volumes are driven by both these continents. Exports from North America, in fact, show slight dip in fourth quarter of 2018.

The ramifications of slowing growth in North America's exports compared to its imports are far-reaching. The trend signifies a shift of global trade control from North America. The protectionist measures undertaken by the U.S. can also be considered in this content. The U.S. most probably understands the ramifications of this trade shift toward Asia, and is actively trying to fight back. However, the mode and efficacy of this response are under question. The unilateralism adopted in the process may well threaten the existence of multilateral trade organizations like the WTO. 
Exports

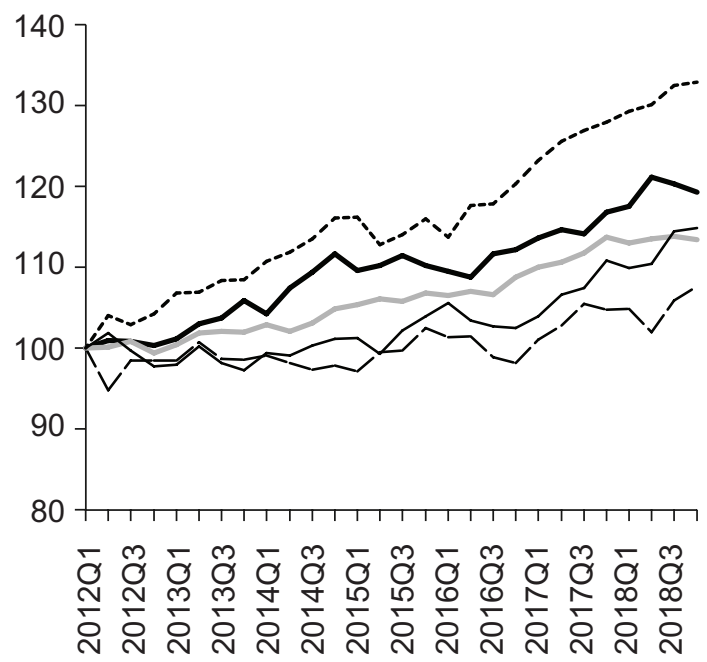

Imports

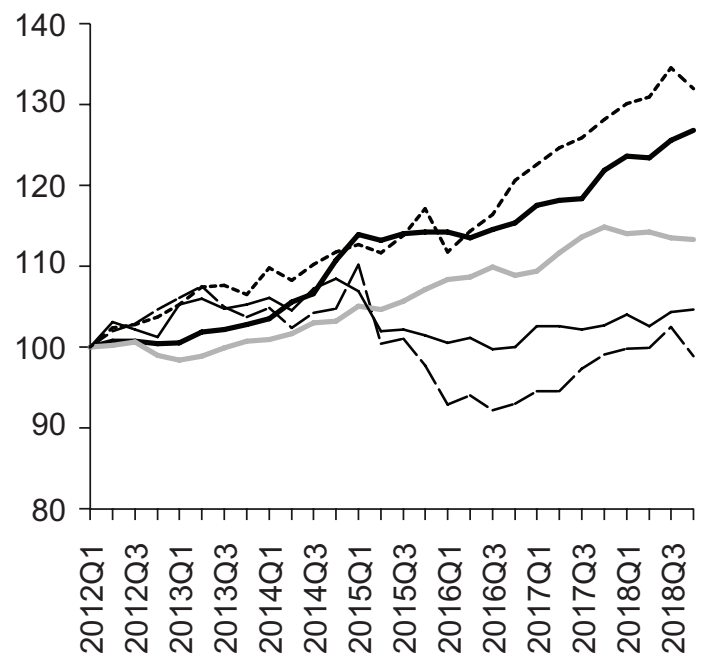

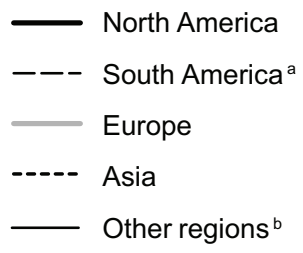

Fig. 3. Merchandise Exports and Imports by Region, 2012Q1-2018Q4 (Volume Index, 2012Q1 = 100)

${ }^{a}$ Refers to South and Central America and the Caribbean.

${ }^{\mathrm{b}}$ Other regions comprise Africa, Middle East and the Commonwealth of Independent States, including associate and former member states.

Source: [WTO, 2019a; 2019b].

While the gradual shift of trade toward Asia is often remarked upon, another significant shift goes relatively unnoticed - the shift of trade away from the developed countries and toward the developing countries. This shift is visible in Fig. 4, where the trends of exports and imports are grouped according to the level of economic development.

World merchandise exports in recent years are principally driven by exports from the developing countries, while developed countries' exports show relative deceleration in growth, particularly after 2017. Once again, the past few quarters show steady growth in the imports of developed countries but slight deceleration in imports of developing countries.

Therefore, the shifting trend is not only away from North America to Asia, but also away from developed countries toward developing countries. In merchandise trade, the shift has been evident for some time and implies a growing comparative disadvantage 
in trade in goods for the developed countries. For quite some time, developed-country manufacturers and industries have been shifting to destinations in Asia and elsewhere with lower labour costs. The flip side of this production base shifting is the current trend.

In a volatile global economy, frittering away export advantages also results in higher current account deficits. Mounting trade deficits can be a problem if international financing of those deficits is not easy. International debt financing in the aftermath of the 2008 crisis has, in fact, become difficult compared to earlier years. Moreover, downward or fluctuating trends in employment in many of developed countries are putting additional domestic pressure on policymakers.

This largely explains the inward-looking policymaking in many of the developed countries. Even during the better years of the WTO, for example, the EU applied stringent non-tariff technical and sanitary barriers to products coming from many developing countries. Apart from health and safety reasons, these notifications often served the purpose of insulating domestic producers from cheaper competitive products. The recent unilateral tariff and/or quota impositions by the U.S. may also be seen in this light.
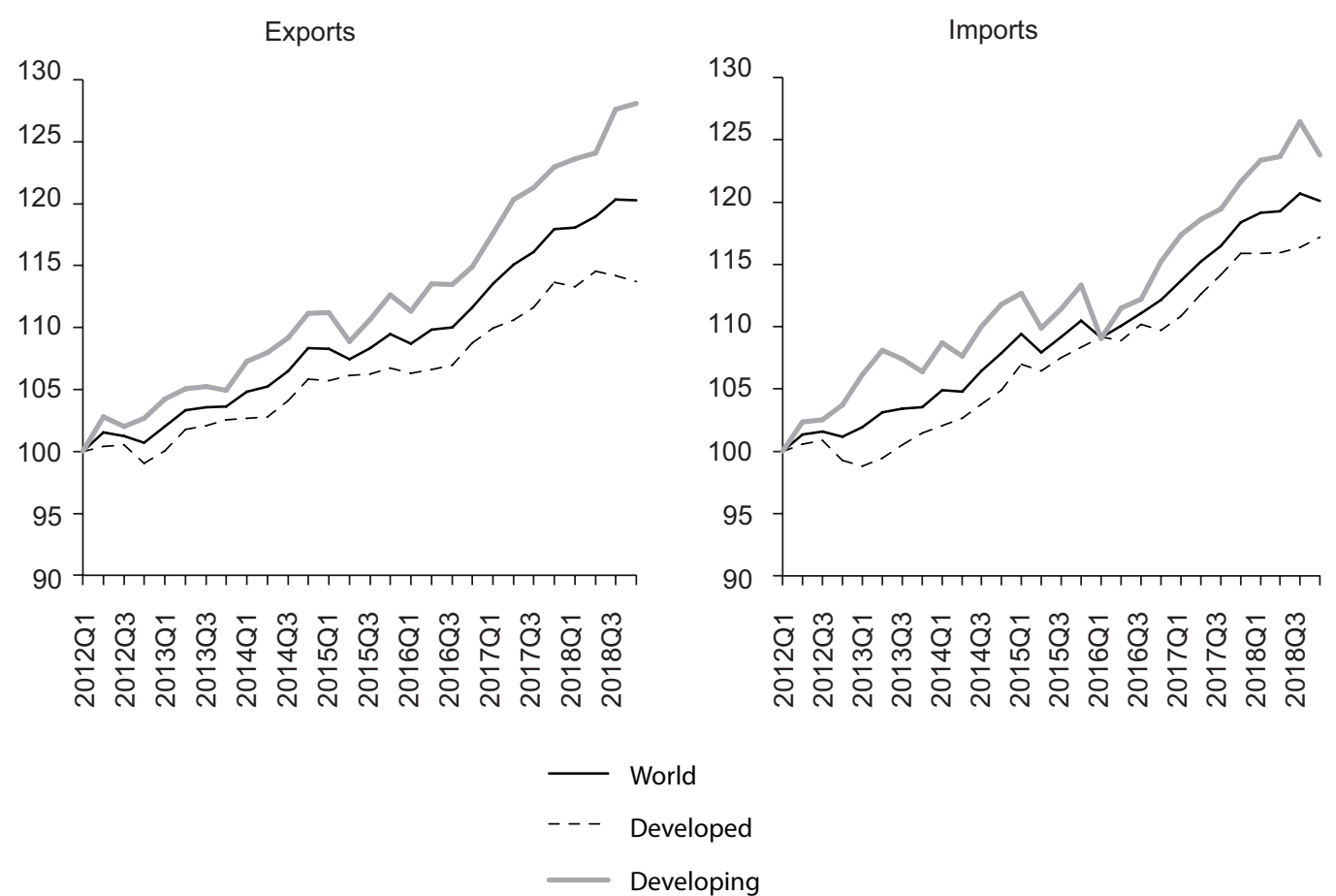

Fig. 4. World Merchandise Exports and Imports by Level of Development, 2012Q1-2018Q4 (Volume Index, 2012Q1 = 100)

Source: [WTO, 2019a; 2019b].

Going by the deceleration in world merchandise trade (as described until now), it may seem that world trade is about to collapse. However, this would be an overstate- 
ment given that the total volume of trade is still growing, mainly due to positive growth rates in services exports.

Fig. 5 shows the percentage growth rates of commercial services exports. Growth of commercial services exports took a hit in 2015, but recovered well over consecutive years. By 2018, all categories of commercial services started experiencing healthy rates of growth.

This is important in order to understand the recent trade conflicts. The developed world, to a great extent, consciously shifted industries (particularly the polluting ones) to various developing destinations, including China. The long-term vision has been to concentrate on services and make a transition from an industrialized economy to a high-tech, service-based economy. Apart from cheap labour, this was one of the major reasons to shift manufacturing to the developing world. The loss in industrial production, both in terms of domestic sales and exports, was expected to be more than compensated for by the gain in technological product and services productions and revenues.

However, in recent years China has also made substantial inroads in both technology and services. One reason for this is the blurring of merchandise production and commercial services. Increasingly, big companies are simultaneously selling products and providing services. For example, a telecom manufacturer often provides telecom services to a different set of clients. China's growing expertise in manufacturing has helped Chinese companies to make inroads in services in those intersections, and as a result to threaten some of the existing commercial service providers in the developed world.

That factor is definitely playing a role in the American sanctions and objections against Chinese telecom companies, including Huawei and ZTE.

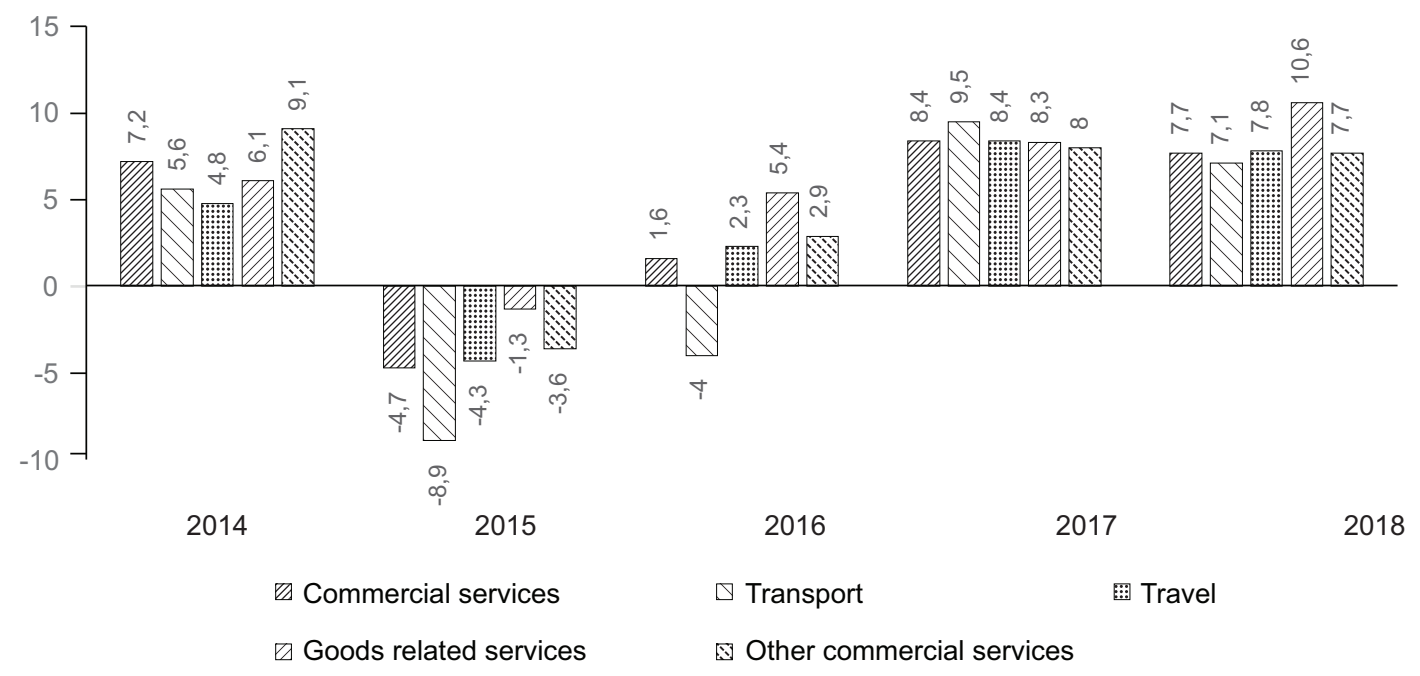

Fig. 5. Growth in Values of Commercial Services Exports by Category, 2014-18

(\% Change in \$ Values)

Source: [WTO, 2019a; 2019b]. 
A look at values and shares of the top 30 merchandise exporters and importers (Table 1) validates this gradual shift of international trade toward Asia. There are 17 Asian countries in the top 30 merchandise exporters (excluding Japan and Russia) and 14 Asian countries in the top 30 importers (excluding Japan, Russia and Israel). Though the top developed countries still hold larger shares in both directions of international trade, the composition of world trade is definitely showing signs of transformation. Countries like Singapore and Korea have been major players for quite some time, but the presence of smaller Asian countries like Indonesia, Vietnam and Bangladesh among the top global exporters and importers signifies the gradual Asian transformation.

Comparison of merchandise trade figures for the U.S. and China also reveals an important fact. China tops the list of leading exporters, with an export volume of $\$ 2,487$ billion and $16.2 \%$ of world export share. The U.S. tops the list of leading importers, with import volume of $\$ 2,614$ billion and $16.6 \%$ of world import share. Thus, China enjoyed an overall merchandise trade surplus of $\$ 351$ billion in 2018, while the U.S. ran an overall merchandise trade deficit of $\$ 950$ billion. This bolsters the point regarding the root cause of the U.S.-China conflict.

Table 1. Leading Merchandise Exporters and Importers Excluding Intra-EU (28), 2018 (\$ Billions and \%)

\begin{tabular}{|c|l|c|c|c|c|l|c|c|c|}
\hline Rank & Exporters & Value & Share & $\begin{array}{c}\text { Annual \% } \\
\text { change }\end{array}$ & Rank & Importers & Value & Share & $\begin{array}{c}\text { Annual \% } \\
\text { change }\end{array}$ \\
\hline 1 & China & 2487 & 16.2 & 10 & 1 & U.S. & 2614 & 16.6 & 9 \\
\hline 2 & $\begin{array}{l}\text { Extra- } \\
\text { EU (28) } \\
\text { Exports }\end{array}$ & 2309 & 15.1 & 9 & 2 & $\begin{array}{l}\text { Extra-EU } \\
(28) \text { Imports }\end{array}$ & 2337 & 14.9 & 11 \\
\hline 3 & U.S. & 1664 & 10.9 & 8 & 3 & China & 2136 & 13.6 & 16 \\
\hline 4 & Japan & 738 & 4.8 & 6 & 4 & Japan & 749 & 4.8 & 11 \\
\hline 5 & Korea & 605 & 3.9 & 5 & 5 & $\begin{array}{l}\text { Hong Kong, } \\
\text { China }\end{array}$ & 628 & 4.0 & 6 \\
\hline 6 & $\begin{array}{l}\text { Hong } \\
\text { Kong, } \\
\text { China }\end{array}$ & 569 & 3.7 & 3 & 6 & Korea & 535 & 3.4 & 12 \\
\hline 7 & Mexico & 451 & 2.9 & 10 & 7 & India & 511 & 3.3 & 14 \\
\hline 8 & Canada & 450 & 2.9 & 7 & 8 & Mexico & 477 & 3.0 & 10 \\
\hline 9 & Russia & 444 & 2.9 & 26 & 9 & Canada & 469 & 3.0 & 6 \\
\hline 10 & Singapore & 413 & 2.7 & 11 & 10 & Singapore & 371 & 2.4 & 13 \\
\hline 11 & UAE & 346 & 2.3 & 10 & 11 & $\begin{array}{l}\text { Chinese } \\
\text { Taipei }\end{array}$ & 286 & 1.8 & 10 \\
\hline 12 & $\begin{array}{l}\text { Chinese } \\
\text { Taipei }\end{array}$ & 336 & 2.2 & 6 & 12 & Switzerland & 279 & 1.8 & 4 \\
\hline 13 & India & 326 & 2.1 & 9 & 13 & UAE & 253 & 1.6 & -6 \\
\hline 14 & $\begin{array}{l}\text { Switzer- } \\
\text { land }\end{array}$ & 311 & 2.0 & 4 & 14 & Thailand & 250 & 1.6 & 13 \\
\hline
\end{tabular}




\begin{tabular}{|c|c|c|c|c|c|c|c|c|c|}
\hline Rank & Exporters & Value & Share & $\begin{array}{c}\text { Annual \% } \\
\text { change }\end{array}$ & Rank & Importers & Value & Share & $\begin{array}{c}\text { Annual \% } \\
\text { change }\end{array}$ \\
\hline 15 & $\begin{array}{l}\text { Saudi } \\
\text { Arabia }^{1}\end{array}$ & 299 & 2.0 & 35 & 15 & Russia $^{2}$ & 249 & 1.6 & 5 \\
\hline 16 & Australia & 257 & 1.7 & 11 & 16 & Vietnam $^{1}$ & 244 & 1.6 & 15 \\
\hline 17 & Thailand & 252 & 1.6 & 7 & 17 & Australia & 236 & 1.5 & 3 \\
\hline 18 & Malaysia & 247 & 1.6 & 14 & 18 & Turkey & 223 & 1.4 & -5 \\
\hline 19 & Vietnam $^{1}$ & 246 & 1.6 & 15 & 19 & Malaysia & 217 & 1.4 & 12 \\
\hline 20 & Brazil & 240 & 1.6 & 10 & 20 & Brazil $^{1}$ & 189 & 1.2 & 20 \\
\hline 21 & Indonesia & 180 & 1.2 & 7 & 21 & Indonesia & 189 & 1.2 & 20 \\
\hline 22 & Turkey & 168 & 1.1 & 7 & 22 & $\begin{array}{l}\text { Saudi } \\
\text { Arabia }^{1}\end{array}$ & 135 & 0.9 & 0 \\
\hline 23 & Norway & 123 & 0.8 & 18 & 23 & Philippines & 115 & 0.7 & 13 \\
\hline 24 & $\operatorname{Iran}^{1}$ & 108 & 0.7 & 16 & 24 & $\begin{array}{l}\text { South } \\
\text { Africa }^{1}\end{array}$ & 114 & 0.7 & 12 \\
\hline 25 & $\begin{array}{l}\text { South } \\
\text { Africa }\end{array}$ & 94 & 0.6 & 6 & 25 & Israel $^{1}$ & 88 & 0.6 & 22 \\
\hline 26 & $\operatorname{Iraq}^{1}$ & 89 & 0.6 & 41 & 26 & Norway & 88 & 0.6 & 6 \\
\hline 27 & Qatar $^{1}$ & 86 & 0.6 & 28 & 27 & Chile & 74 & 0.5 & 14 \\
\hline 28 & Chile & 75 & 0.5 & 9 & 28 & Egypt & 72 & 0.5 & 17 \\
\hline 29 & Kuwait $^{1}$ & 72 & 0.5 & 30 & 29 & Argentina & 65 & 0.4 & 16 \\
\hline \multirow[t]{3}{*}{30} & Philippines & 67 & 0.4 & -2 & 30 & Bangladesh $^{1}$ & 62 & 0.4 & 16 \\
\hline & Total $^{3}$ & 14052 & 91.7 & - & & Total $^{3}$ & 14255 & 90.7 & - \\
\hline & $\begin{array}{l}\text { World } \\
\text { [excl. intra- } \\
\text { EU (28)] }\end{array}$ & 15319 & 100 & 10 & & $\begin{array}{l}\text { World [excl. } \\
\text { intra-EU } \\
(28)]^{3}\end{array}$ & 15710 & 100 & 10 \\
\hline
\end{tabular}

${ }^{1}$ WTO Secretariat estimates.

${ }^{2}$ Imports are valued f.o.b.

${ }^{3}$ Includes significant re-exports or imports for re-export.

Source: [WTO, 2019a].

If the export and import figures for Hong Kong are also added, even then China and Hong Kong hold an overall trade surplus of $\$ 292$ billion, almost equal to total exports of oil-rich Saudi Arabia. This puts China's immense gain in trade over the last two decades into perspective.

It should also be remembered that a sizeable number of Chinese manufacturers have shifted or are planning to shift their bases to other Asian countries, including Malaysia, Vietnam and Thailand. So, implicitly, a portion of the positive trade results enjoyed by these smaller countries will automatically contribute to China's rise in the future.

A rising China in international trade will definitely put the U.S. - the current leader of the GDP pack - on alert. Though many experts and commentators ex- 
press astonishment at the U.S.'s unilateral tariff imposition, if one views the conflict purely in terms of trade statistics then it is not unexpected at all. This was bound to happen. However, questions may be asked about the mode of current U.S. reactions to China in a rules-based international trade system of which the WTO is an integral part.

\section{The Slowdown in Global Trade and Economic Growth}

Looking at the trend in world exports growth since the 1980s, a few facts become quite clear. The first is the acceleration in world trade since the inception of World Trade Organization in 1995.

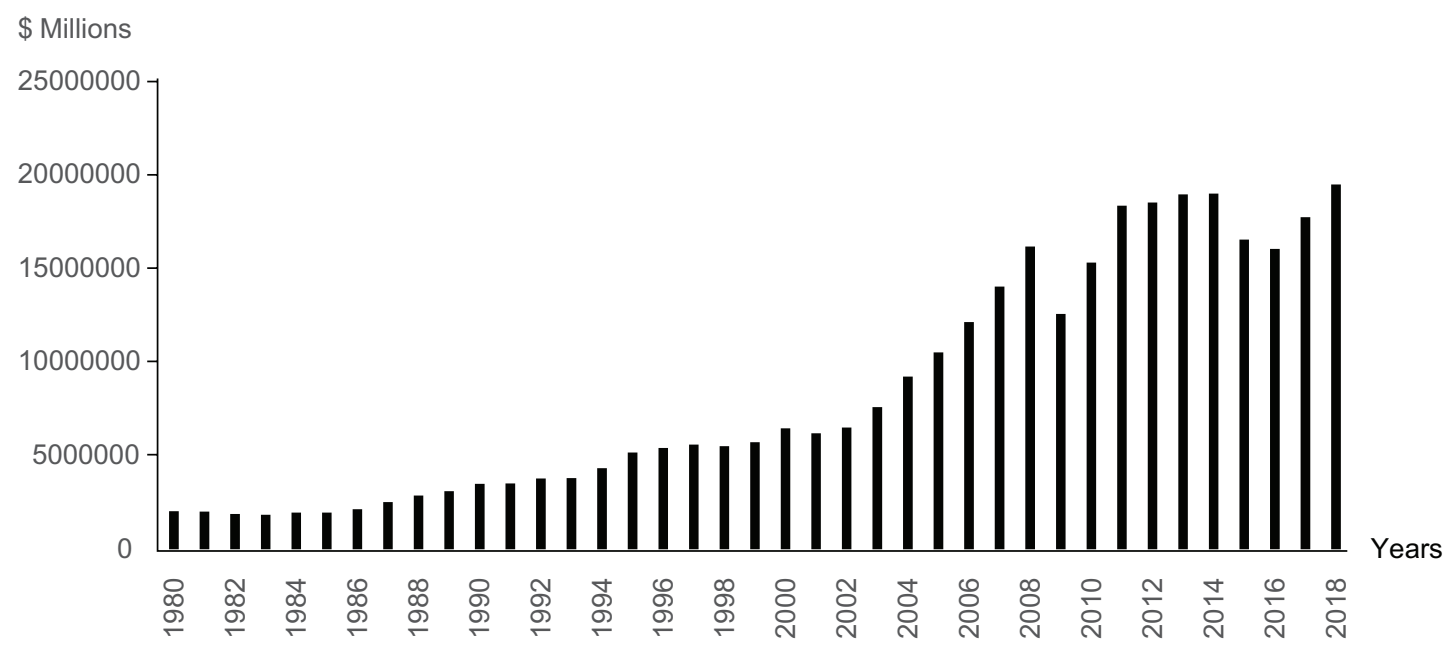

Fig. 6. Trend in World Exports Since the 1980s (\$ Millions)

Data source: [WTO, n.d.].

This acceleration lasted until the world was hit by the transatlantic financial crisis of 2008 which originated from the housing mortgage segment of the U.S. financial market. In the context of the currently turbulent international trade scenario, it is no exaggeration to say that the "golden period of international trade" which began in 1995 is now over, replaced by a conflictual era of tariff wars that are threatening to spoil the positive influences the golden period imparted on the world economy.

Fig. 6 shows world exports since 1980. After a sharp drop in world export volume in 2009 , the growing trend showed what initially looked like a recovery in the subsequent years. But, the data since 2010 exhibits a stagnating trend at the same level, as if the volume of world exports had reached a plateau. In fact, world exports once again started declining in 2015 before going up in 2017. However, the overall volume shows similar mountain table-top characteristics. This is a distinct sign of slowdown in international trade and business growth however one interprets the data. 
Trade has been an important driver of economic growth globally. Therefore, a slowdown or a stagnation in trade growth is likely to induce a slowdown in global economic growth.

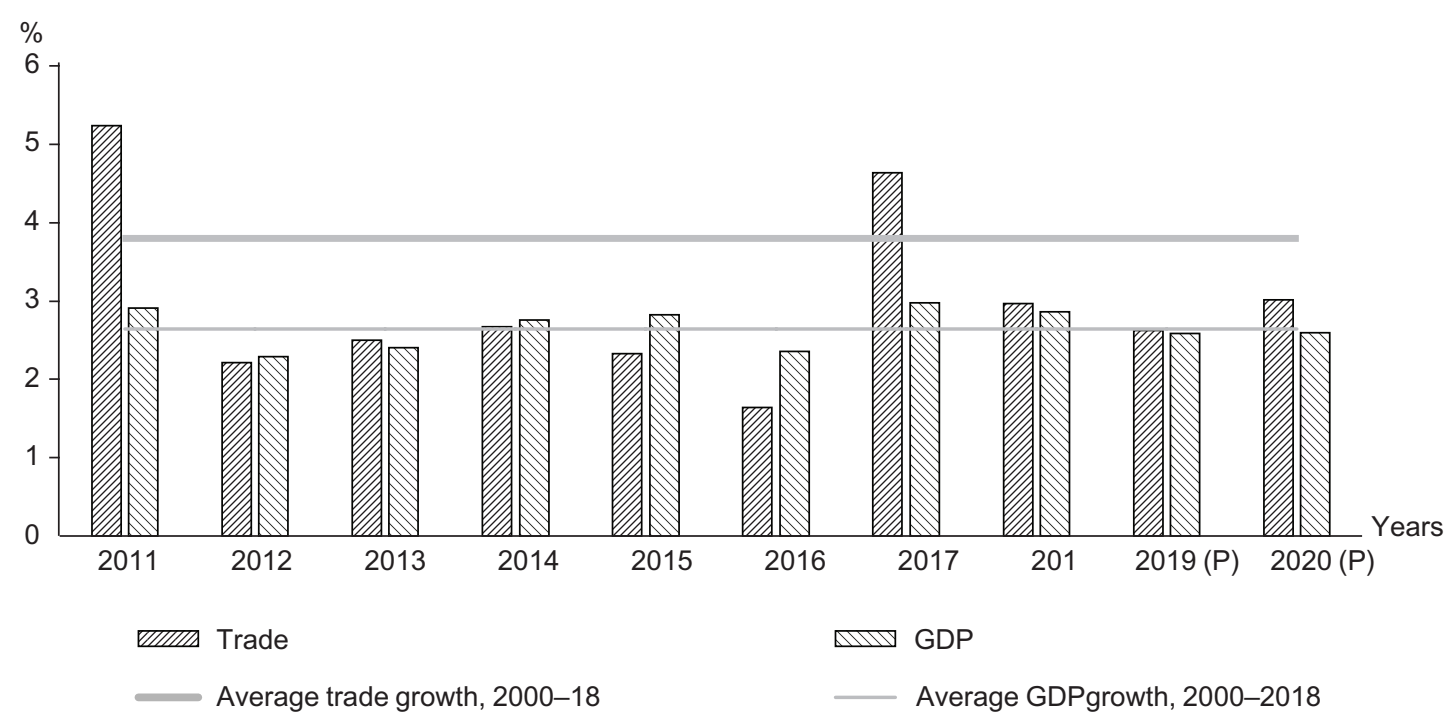

Fig. 7. World Merchandise Trade Volume and Real GDP Growth, 2011-20 (Annual \% Change)

* GDP is measured at market exchange rates; data for 2019 and 2020 are projections.

Source: [WTO, 2019a; 2019b].

Fig. 7 shows the relationship between trade growth and GDP growth for the world. An overall slowdown in world output has been adversely affecting trade growth since 2012. The above-average trade growth of 4.6\% in 2017 raised hope of a recovery. Unfortunately, trade wars, weak economic growth, volatile financial markets and tighter monetary conditions weighed down any chance of a global recovery.

Apart from the exceptional years of 2011 and 2017, trade volume growth and real GDP growth show a close relationship. In last two decades, healthy export growth has been instrumental in economic prosperity of many economies, including China. It is often said that a huge part of the world's population has been taken out of poverty in the last two decades. It has only been possible because of this economic growth. However, this chain of trade and economic prosperity is seemingly under serious threat at the current juncture.

As can be observed in Fig. 7, the WTO estimates that merchandise trade volume growth will fall to $2.6 \%$ in 2019, and expects trade growth to rebound to $3 \%$ in 2020 .

However, WTO director-general Roberto Azevêdo said, "With trade tensions running high, no one should be surprised by this outlook. Trade cannot play its full role in driving growth when we see such high levels of uncertainty. It is increasingly urgent that we resolve tensions and focus on charting a positive path forward for global trade which responds to the real challenges in today's economy - such as the technological revo- 
lution and the imperative of creating jobs and boosting development. WTO members are working to do this and are discussing ways to strengthen and safeguard the trading system. This is vital. If we forget the fundamental importance of the rules-based trading system we would risk weakening it, which would be an historic mistake with repercussions for jobs, growth and stability around the world" [WTO, 2019a].

While it is heartening to see the WTO recognizing the risks of trade tensions in 2019, its position on U.S. unilateralism to date has been vague at best.

\section{Worrying Trends for Multilateralism and Developing Economies}

The World Bank (WB), International Monetary Fund (IMF) and WTO together published a policy paper in September 2018 entitled Reinvigorating Trade and Inclusive Growth which charted directions for future international trade reform. The paper should be read in the context of these changing winds of international trade, and highlights worrying trends for developing and emerging economies in the near future.

Surprisingly, the paper does not criticize the unilateral tariff impositions of recent times even once, and instead mentions (only once) at the beginning that the "system of global trade rules that has nurtured unprecedented economic growth across multiple generations faces tensions. Though only recently brought to the fore, those tensions are rooted in issues that have been left unresolved for too long. Governments need to promptly address outstanding questions involving, for example, the WTO dispute system and the reach of subsidy disciplines."

This is nothing but a backhand justification for the American imposition of unilateral tariffs.

The WTO secretariat technically cannot be party to such a biased proposal for the reform of international trade as it does not have any decision-making power. In the WTO, all decisions are taken by the member countries only, and the secretariat's duties are "to support various councils and committees, to provide technical assistance, to monitor and analyze developments in world trade, to provide information to public and media, and to organize the ministerial conferences." 4 The ministerial conference is the highest decision-making body in the WTO under the existing framework.

The WB-IMF-WTO policy paper goes on to say that "... reliance on an approach in which all members must agree on all issues risks driving negotiating activity outside the WTO. Agreeing among so many members, each with unique challenges and priorities, has proven difficult." Since its inception, a consensus-based multilateralism has been the bedrock of the WTO and is the primary reason behind its immense success in promoting free trade in the past. Not so subtly, the WB-IMF-WTO proposal challenges that consensus-based approach of trade negotiations.

The paper then makes an argument to employ a "plurilateral" and "flexible" approach in negotiations within the WTO on any issue where consensus does not emerge as "the practice of bundling negotiating issues together in a giant, all-or-nothing trade rounds has become extremely difficult to manage." This is like proposing separate

\footnotetext{
${ }^{4}$ Role of WTO Secretariat is taken from the WTO website [WTO, n.d.].
} 
clubs within the WTO, and essentially treating some groups of countries as superior to other groups of countries. It is an absurd idea to sustain in a multilateral forum where all countries are supposed to be treated at par with each other. It is like saying that any country is free to negotiate its own kind of bilateral or plurilateral deals under the WTO umbrella. But, why would countries do that under the WTO when they have the option of doing it independently outside the forum? It looks like a desperate attempt of the WTO to remain relevant in international trade.

In contrast to these arguments, the policy paper then advocates for a universal approach to investment to set "holistic rules critical in a world of regional and global value chains." It also reiterates the necessity of resolving thorny issues like market access in agriculture, distortions in agricultural trade, regulatory cooperation and e-commerce. While acknowledging the variability of interests on these issues, the paper prescribes the "evolution" and "modernization" of rules, policies and practices governing global trade.

If one reads between the lines, this implies that accommodating the different obligations of emerging economies and less-developed countries in the implementation of tariff schedules and service commitments may come under scanner scrutiny under this "flexible" approach to trade negotiations in future. On questions like market access, the possibility of future arm-twisting cannot be ruled out. Countries like India, Brazil and China will be adversely affected in future if this proposed approach is accepted at the level of the WTO.

\section{The U.S.'s Blocking of Attempts to Fill WTO Appellate Body Vacancies}

Meanwhile, the U.S. has single-handedly blocked a proposal for filling vacancies of the WTO's Appellate Body (AB) as it feels that in the past the body went beyond its mandate in its rulings. This is another part of the broad American narrative that "the system is rigged against us." The AB is a standing body of seven people that hears appeals from reports/rulings issued by dispute settlement panels at the WTO. The AB's reports, once adopted by the Dispute Settlement Body, must be accepted by all the parties involved under the existing rules and procedures governing the settlement of disputes at the WTO.

Due to the U.S.'s blocking of new appointments in the past two years, the AB is now reduced to three members from seven. By December 2019, the AB will be reduced to a single member when members from India and the U.S. retire at the end of their second terms. India joined the EU, China, Canada, Norway, New Zealand, Switzerland, Australia, Korea, Iceland, Singapore and Mexico to issue a joint proposal to fill the vacancies on 26 November. However, using its veto power the U.S. once again rejected the proposal on 12 December, and called the EU, India and China the "new trilateral" (at the WTO) - which is trying to "change the rules to authorise and accommodate the very approaches that would make the Appellate Body even less accountable" [Kanth, 2018]. 
This persistent effort to block the filling of vacancies on the Appellate Body seems to be an American ploy to go back to the pre-1995 GATT (General Agreement on Tariffs and Trade) phase where the rulings of any dispute settlement panel could be negotiated as opposed to the AB's mandatory implementation under the current twostage dispute settlement system. If that happens then it will be a telling blow to the credibility of the WTO.

So, trade battles are being fought in different multilateral spheres beyond the tariff front, and there are enough reasons to be sceptical about a bright future for international trade [Mukhopadhyay, 2018b].

\section{The Need for Trade Cooperation Outside the WTO}

This does not bode well for the emerging economies, including the BRICS countries of Brazil, Russia, India, China and South Africa. These countries negotiated hard for deferment of tariff schedules and services commitments in the past to protect their own economic and development interests [Brenton, Newfarmer, 2009; BRICS, 2018]. Under the proposed "plurilateral flexible" approach those benefits may just disappear.

According to the trade reform proposal advocated by the WB-IMF-WTO trio, the cost of unilateral tariff impositions started by the U.S. will be borne by the countries of the world which are growing the fastest - the BRICS countries and the Next Eleven. ${ }^{5}$ It is unlikely that multilateral organizations like the WTO will have the requisite instruments to stop unilateral and arbitrary trade decision-making by the United States. The economic and political might of America, on the contrary, is likely to bend these institutions to the U.S.' favour.

After the 2008 financial crisis, international platforms like the Group of G7 and the Group of 20 solidified their cooperation in regulating financial markets across the world to provide stability to the international monetary system. In contrast, formations like BRICS evolved through a larger cooperation in international trade negotiations. In other words, trade blocs or formations based on south-south cooperation have larger stakes in the multilateral rules-based WTO. Unfortunately, the WTO does not seem to be the saviour of these countries this time.

Before the trade war erupted last year, increasing globalization resulted in the proliferation of large multinational companies all over the world. Globalization plugged businesses from different countries, and primarily China, into global value chains, the development of which strengthen the case for regional integration. Creating trade and business opportunities requires strong regional cooperation to remove barriers to customs and investment, and facilitate the activities of value chains. For example, a Chinese company making a product in factories in Vietnam and utilizing inputs from Indonesia and Thailand would find it much easier to do business if there was a formal regional economic cooperation agreement among all of these countries.

${ }^{5}$ The Next Eleven countries are Bangladesh, Egypt, Indonesia, Iran, Mexico, Nigeria, Pakistan, Philippines, Korea, Turkey and Vietnam. 
Therefore, there has been a tendency toward regional trade negotiations in the new millennium, particularly in different Asian regions. Even before the present trade turmoil, there have been conscious efforts from various countries to increase Asian economic integration. Quite a few significant economies, including China, possibly also sensed the shift of trade and economic development toward Asia.

East Asian economies were among the first few to realize the potential of regional trade cooperation and integration. Probably, these countries took a lesson or two from the EU. Comprehensive and well-designed free trade agreements (FTAs) resulted in various economic benefits, including preferential tariffs, market access and new business opportunities. A proliferation of FTAs and FTA negotiations over the last two decades can be observed in East Asia, as evidence. Several of these are important to mention to the extent that they provide insight into the various modes adopted by different Asian countries looking for opportunities in the context of trade turmoil.

The Association of Southeast Asian Nations (ASEAN) ${ }^{6}$ is the oldest forum for economic and trade cooperation in the region. Currently, it has FTAs with China, Japan, Korea, India, Australia and New Zealand. These ASEAN+ agreements are expected to bring dynamic economic benefits for all countries involved in the near future. Trade volumes have increased because of these FTAs, but only detailed analyses, which are beyond the scope of this paper, can reveal the extent of the benefits accrued by related countries like India. ASEAN will remain an important element in the consolidation of regional trade in Asia in the future [Minghui, 2018].

There has been a serious attempt to consolidate 12 countries across the Asia Pacific and Atlantic regions to create a free trade area in the Trans-Pacific Partnership (TPP). ${ }^{7}$ A salient element of the TPP was the exclusion of China from the agreement. This was clearly an attempt by the trio of the U.S., Canada and Japan to establish a gigantic trade footprint both in South America and the Asia Pacific. By 2008, the trio had joined an initial trade formation made up of Brunei, Chile, New Zealand and Singapore. The TPP did not materialize as the U.S. subsequently withdrew, but the Comprehensive and Progressive Agreement for Trans-Pacific Partnership (CPTPP) - without the U.S. - was signed by rest of the participants in January 2018.

The TPP represented a significant effort on the part of the U.S. to re-assert and consolidate its trade dominance. In response, China sought to create a counter to the initiative, leading to the idea of the Regional Comprehensive Economic Partnership $(\mathrm{RCEP})^{8}$ in 2012. The aim of RCEP is to create an open market with a higher level of liberalization than that which exists between the five ASEAN+ FTAs by integrating the complex networks and untangling the negative "spaghetti bowl effect" in the

\footnotetext{
${ }^{6}$ ASEAN currently is comprised of 10 member countries (Vietnam, Thailand, Singapore, Philippines, Myanmar, Malaysia, Laos, Indonesia, Cambodia and Brunei).

${ }^{7}$ The TPP did not materialize due to withdrawal of the United States. The original plan was to strike an agreement to create a free trade area among Australia, Brunei, Canada, Chile, Japan, Malaysia, Mexico, New Zealand, Peru, Singapore, Vietnam and the United States.

${ }^{8}$ Currently, RCEP negotiations are going on between the ASEAN member states and its six FTA partners.

${ }^{9}$ Bhagwati [2002] and many others used the term. Bhagwati called the proliferation of FTAs an "unruly mass of criss-crossing strings," and opined that this ever more complex maze of FTAs need not lead to a uniform expansion of trade. Instead, it may turn some countries into hubs and others into spokes.
} 
region. China, particularly, treated the RCEP as the alternative to the TPP [Pangestu, Armstrong, 2018].

Although the U.S. ultimately pulled out of the TPP, the rapidly changing tradewar-like situation prevailing in international business means that the RCEP remains very relevant to China [He, Pan, 2015]. With the imposition of tariffs and embargos on all kinds of Chinese exports to the U.S. in effect, China is bound to lose parts of its export volume in the short run. And in the long run, the country definitely has to look for alternative destinations for its exports. This is crucial for the Chinese economy as the success of the Chinese model of economic growth hinges on its export-oriented strategy. China currently is leaving no stone unturned as it explores all kinds of export possibilities.

An important point to note is that even before the trade war started major economies (including the U.S. and China) were scouting for trade cooperation outside the framework of the WTO. With the major economies of the world doing so, the rest including the developing countries - were left with no choice other than to form a regional trade cooperation of their own. The need to cooperate in trade should be viewed from this perspective as well.

However, there is a glitch in this mode of trade cooperation for the Asian countries. It has been observed in the past that trade within Asian regions is dominated by intermediate products. Almost half of all intermediate goods are assembled in Asia, particularly in mainland China. Those final assembled goods are consumed mostly in markets outside Asia, including the U.S. and the EU. Demand for final goods (that is, final consumption) from outside economies accounted for more than $70 \%$ of Asian exports even in 2007 [ADB, 2010; Kawai, Ganeshan, 2010]. This has a serious implication. If consumption demand for final goods from Asian regions does not rapidly rise, then the export dependence on developed markets may become a spoiler for the developing nations, at least in the short run. Therefore, emerging economies have to be careful when making choices about their trade partners in the current trade chaos. Otherwise, with a fair number of intermediate goods in their export baskets these countries run the risk of getting stranded in international export markets with their goods unsold. In other words, based on its the position and status in the global value chain (as raw material supplier, intermediate goods supplier or final finished product supplier), a country must choose trade partners with care and caution.

The ray of hope for the developing countries, however, lies in the fact that upcoming fast-growing future markets of consumers are unlikely to originate from the U.S. or Western Europe. The next billion consumers are expected to come from BRICS and Next Eleven countries. Future international games of trade manoeuvres will revolve around the capture of this emerging future consumer base [Mukhopadhyay, 2019a; 2019b].

Now, when multilateralism is in dire straits and the immediate future is not looking bright, all developing countries urgently need to prepare and plan for more protectionism in international trade. Only deeper cooperation among themselves can protect 
their interests in the new world trade order, which may decisively tilt toward the advanced industrialized countries, at least in the short run.

\section{References}

Asian Development Bank (ADB) (2010) Institutions for Regional Integration: Toward an Asian Economic Community. Philippines: ADB. Available at: https://www.adb.org/publications/institutions-regionalintegration-toward-asian-economic-community.

BBC News (2018) US-China Trade War: New Tariffs Come Into Force. 23 August. Available at: https:// www.bbc.com/news/business-45255623 (accessed 5 September 2018).

Bhagwati J.N. (2002) Free Trade Today. Princeton: Princeton University Press.

Brenton P., Newfarmer R. (2009) Watching More Than the Discovery Channel to Diversify Exports. Policy Research Working Paper No 4302, International Trade Department, The World Bank. Available at: https://elibrary.worldbank.org/doi/abs/10.1596/1813-9450-4302 (accessed 23 July 2019).

BRICS (2018) Johannesburg Declaration. Johannesburg, 26 July. Available at: https://www.mea.gov.in/ bilateral-documents.htm?dtl/30190/10th_BRICS_Summit_Johannesburg_Declaration (accessed 30 July 2018).

Chakraborty S. (2018) US-China Tariff War to Slow Down Global Trade Growth in Q3 of CY18: WTO. Business Standard, 10 August. Available at: https://www.business-standard.com/article/international/ us-china-tariff-war-to-slow-down-global-trade-growth-in-q3-of-cy18-118080901574_1.html (accessed 21 September 2018).

Ciuriak D. (2018) The March Into Trade Wars: US Policy Aims and the Implications for Reconciliation. Verbatim, C.D. Howe Institute. Available at: https://papers.ssrn.com/sol3/papers.cfm?abstract id $=3214788$ (accessed 18 September 2018).

Dhar B. (2018) Trade Wars of the United States. Economic and Political Weekly, vol. 53, no 37, pp. 12-7. Available at: https://www.epw.in/journal/2018/37/commentary/trade-wars-united-states.html.

Dutt A.K. (2006) Maturity, Stagnation and Consumer Debt: A Steindlian Approach. Metroeconomica, vol. 57, no 3, pp. 339-64. Available at: https://doi.org/10.1111/j.1467-999X.2006.00246.x.

Grennes T. (2017) The Economics of Tariffs: Can Restricting International Trade be Good for the Economy. NC State Economist, May/June. Available at: https://cals.ncsu.edu/agricultural-and-resourceeconomics/wp-content/uploads/sites/12/2018/03/Economist-Grennes-May-June-2017.pdf (accessed 17 September 2018).

Guttman R., Plihon D. (2008) Consumer Debt at the Center of Finance-Led Capitalism. Available at: http:// citeseerx.ist.psu.edu/viewdoc/download?doi=10.1.1.640.7792\&rep=rep1\&type=pdf (accessed 10 November 2019).

He F., Pan X. (2015) China's Trade Negotiation Strategies Matters of Growth and Regional Economic Integration. China's Domestic Transformation in a Global Context (L. Song, R. Garnaut, C. Fang, L. Johnston (eds)). Canberra: ANU Press.

International Monetary Fund (IMF), The World Bank (WB), and World Trade Organization (WTO) (2018) Reinvigorating Trade and Inclusive Growth. IMF Policy Paper. Available at: https://www.imf.org/ en/Publications/Policy-Papers/Issues/2018/09/28/093018-reinvigorating-trade-and-inclusive-growth (accessed 21 November 2018).

Kawai M., Ganeshan W. (2010) Asian FTAs: Trends, Prospects and Challenges. ADB Economics Working Paper Series No 226, Asian Development Bank. Available at: https://www.adb.org/sites/default/ files/publication/28273/economics-wp226.pdf (accessed 18 August 2019).

Ravi Kanth, D. (2018). EU, India and China 'new trilateral' at WTO, says US. LiveMint, Published 14 December. Available at: https://www.livemint.com/Politics/OW27Fz7PRnfqyL2OinYGiO/EU-India-and-China-new-trilateral-at-WTO-says-US.html (accessed 2 February 2019). 
Krugman P.R., Obstfeld M. (2009) International Economics: Theory and Policy. Indian Edition. India: First Impression Pearson Education.

Lerner A.P. (1936) The Symmetry Between Import and Export Taxes. Economica New Series. vol. 3, no 11, pp. 306-13. Available at: https://doi.org/10.2307/2549223.

Minghui S. (2018) Evaluation of Regional Economic Integration in East Asia. Asian Economic Integration in an Era of Global Uncertainty (S. Armstrong, T. Westland (eds)). Canberra: ANU Press.

Montgomerie J. (2007) The Logic of Neo-Liberalism and the Political Economy of Consumer Debt-Led Growth. Neo-Liberalism, State Power and Global Governance (S. Lee, S. McBride (eds)). The Netherlands: Springer.

Mukhopadhyay A. (2018a) Is China's Loss, India's Gain? An Examination of the US Tariff War. ORF Occasional Paper No 175, Observer Research Foundation. Available at: https://www.orfonline.org/research/china-loss-india-gain-examination-us-tariff-war-45623/ (accessed 28 January 2019).

Mukhopadhyay A. (2018b) Trade War Games: Unity Among BRICS and Next Eleven Countries Will Be the Key. ORF Expert Speak, Observer Research Foundation. Available at: https://www.orfonline.org/expert-speak/trade-war-games-unity-among-brics-next-eleven-countries-key-46351/ (accessed 28 January 2019).

Mukhopadhyay A. (2019a) India at a Crossroads. World Commerce Review, vol. 13, no 2, pp. 36-40. Available at: https://www.worldcommercereview.com/html/mukhopadhyay-india-at-a-crossroads.html (accessed 29 August 2019).

Mukhopadhyay A. (2019b) Will G-20 Summit be Able to Douse the Trade War Inferno? ORF Expert Speak, Observer Research Foundation. Available at: https://www.orfonline.org/expert-speak/will-g20-summit-be-able-to-douse-the-trade-war-inferno-52526/ (accessed 18 July 2019).

Pangestu M., Armstrong S. (2018) Asian Economic Integration: The State of Play. Asian Economic Integration in an Era of Global Uncertainty (S. Armstrong, T. Westland (eds)). Canberra: ANU Press.

Partington R., Rushe D. (2018) Trump Hits China With \$200bn of New Tariffs as Trade War Escalates. The Guardian, 18 September. Available at: https://www.theguardian.com/us-news/2018/sep/17/donaldtrump-united-states-threatens-to-impose-200bn-import-tariffs-on-china-in-trade-war (accessed 21 November 2018).

United Nations Conference on Trade and Development (UNCTAD) (2018) Power, Platforms and the Free Trade Delusion. Trade and Development Report 2018. Available at: https://unctad.org/en/PublicationsLibrary/tdr2018_en.pdf (accessed 14 January 2019).

The United States Census Bureau, The U.S. Department of Commerce. Available at: https://www.census.gov/ (accessed 5 November 2019).

The United States Trade Representative Office (USTR) (2018) Findings of the Investigation Into China's Acts. Policies, and Practices Related to Technology Transfer, Intellectual Property, and Innovation under Section 301 of the Trade Act of 1974. 22 March. Available at: https://ustr.gov/sites/default/files/Section\%20301\%20FINAL.PDF (accessed 8 November 2019).

World Trade Organization (WTO) (2018) World Trade Outlook Indicator Signals Further Loss of Momentum in Trade Growth into Q4. World Trade Outlook Indicator, 26 November. Available at: https:// www.wto.org/english/news_e/news18_e/wtoi_26nov18_e.htm (accessed 5 January 2019).

World Trade Organization (WTO) (2019a) Global Trade Growth Loses Momentum as Trade Tensions Persist. Press Release No 837, 2 April. Available at: https://www.wto.org/english/news_e/pres19_e/ pr837_e.htm (accessed 19 August 2019).

World Trade Organization (WTO) (2019b) World Trade Statistical Review 2019. Available at: https:// www.wto.org/english/res_e/statis_e/wts2019_e/wts19_toc_e.htm (accessed 21 August 2019). 


\section{Изменения в международной торговле в условиях нестабильного миропорядка ${ }^{1}$}

\section{А. Мукхопадхьяй}

Мукхопадхьяй Абхиджит - с.н.с. (направление «Экономика и рост»), исследовательская организация Observer Research Foundation; 20 Rouse Avenue, New Delhi, 110002, India; E-mail: a.mukhopadhyay@orfonline. org

Режим международной торговли вступил в турбулентную фазу на фоне усиления тенденций торговой войны по всему миру. То, что на первый взгляд выглядит хаотичной политикой, ориентированной на внутренние факторы, на самом деле является битвой за торговое и технологическое превосходство между США и Китаем. Медленное, но устойчивое смещение международной торговли и бизнеса от Северной Атлантики и Западной Европь в сторону Азии создает фон этого конфликта. Также начала проявляться тенденция аналогичного смещения от развитых к развивающимся странам. В этом смысле битва за превосходство была неизбежной, так как Китай сыграл главную роль в этом сдвиге.

При этом «золотая эра торговли», ознаменовавшаяся укреплением ВТО, закончилась, в то время как многосторонность в торговле находится в коматозном состоянии. Быстрорастущие экономики, в том числе страны с формирующейся рыночной экономикой, будут нести основную часть бремени этого кризиса мировой торговли.

Два главных героя этой эпической битвы, Китай и США, каждый по-своему ищут альтернативные источники экономического процветания. В отсутствие многосторонней платформы для торговли план действий для развивающихся стран становится яснее с каждым днем. Эти страны должны искать возможности заключения торговых союзов, в которых каждая из них может получить экономическую выгоду. Для этого каждая из стран должна проанализировать свою экономику, а затем выбирать соответствующих торговых партнеров. Неготовность справиться с хаосом в торговле может привести к катастрофическим последствиям для этих стран.

Ключевые слова: торговые войны; ВТО; международная торговля; многосторонность; региональное сотрудничество

Для цитирования: Мукхопадхьяй А. (2019) Изменения в международной торговле в условиях нестабильного миропорядка // Вестник международных организаций. Т. 14 . № 4. С. 89-111 (на русском и английском языках). DOI: 10.17323/1996-7845-2019-04-05.

\section{Источники}

Asian Development Bank (2010) Institutions for Regional Integration: Toward an Asian economic community. Philippines: ADB.

BBC News (2018) US-China Trade War: New Tariffs Come into Force. 23 August. Режим доступа: https:// www.bbc.com/news/business-45255623 (дата обращения: 05.09.2018).

Bhagwati J.N. (2002) Free Trade Today. Princeton NJ: Princeton University Press

Chakraborty S. (2018) US-China Tariff War to Slow Down Global Trade Growth in Q3 of CY18 // Business Standard. 10 August. Режим доступа: https://www.business-standard.com/article/international/uschina-tariff-war-to-slow-down-global-trade-growth-in-q3-of-cy18-118080901574_1.html (дата обращения: 21.09.2018).

\footnotetext{
${ }^{1}$ Статья поступила в редакцию в сентябре 2019 г.
} 
Dhar B. (2018) Trade Wars of the United States // Economic and Political Weekly. Vol. 53. No. 37. P. 12-17.

Dutt A.K. (2006) Maturity, Stagnation and Consumer Debt: A Steindlian approach // Metroeconomica. Vol. 57. No. 3. P. 339-564.

Guttman R., Plihon D. (2008) Consumer Debt at the Center of Finance-Led Capitalism. Режим доступа: http://citeseerx.ist.psu.edu/viewdoc/download?doi=10.1.1.640.7792\&rep=rep1\&type=pdf $\quad$ дата обращения: 10.11.2018).

IMF-WB-WTO - International Monetary Fund, The World Bank, and World Trade Organization (2018) Reinvigorating Trade and Inclusive Growth. 30 September. Режим доступа: https://www.imf.org/en/ Publications/Policy-Papers/Issues/2018/09/28/093018-reinvigorating-trade-and-inclusive-growth (дата обращения: 10.11.2018).

Montgomerie J. (2007) The Logic of Neo-Liberalism and the Political Economy of Consumer Debt-Led Growth. Neo-Liberalism, State Power and Global Governance / S. Lee, S. McBride (eds). The Netherlands: Springer.

Partington R., Rushe D. (2018) Trump Hits China with \$200bn of New Tariffs as Trade War Escalates // The Guardian. 18 September. Режим доступа: https://www.theguardian.com/us-news/2018/sep/17/donaldtrump-united-states-threatens-to-impose-200bn-import-tariffs-on-china-in-trade-war (дата обращения: 21.11.2018).

United Nations Conference on Trade and Development (UNCTAD) (2018) Trade and Development Report 2018. United Nations. Режим доступа: https://unctad.org/en/PublicationsLibrary/tdr2018_en.pdf (дата обращения: 14.01.2019).

The United States Trade Representative Office (USTR) (2018) Findings of the Investigation into China's Acts. Policies, and Practices Related to Technology Transfer, Intellectual Property, and Innovation under Section 301 of the Trade Act of 1974. 22 March. Режим доступа: https://ustr.gov/sites/default/files/Section\%20 301\%20FINAL.PDF (дата обращения: 08.11.2019).

Wouters J., Van Kerckhoven S. (2017) The G20 and the BRICS on Trade and Investment: Trends and Policies // International Organisations Research Journal. Vol. 12. No. 3. P. 7-31. DOI: 10.17323/1996-7845-2017-03-7.

World Trade Organisation (WTO) (n.d.) World Trade Organization - Home page. Режим доступа: wto.org/ (дата обращения: 21.08.2019).

World Trade Organization (WTO) (2018) World Trade Outlook Indicator. 26 November. Режим доступа: https://www.wto.org/english/news_e/news18_e/wtoi_26nov18_e.htm (дата обращения: 21.08.2019).

World Trade Organization (2019a) Press Release: Global Trade Growth Loses Momentum as Trade Tensions Persist. 2 April. Режим доступа: https://www.wto.org/english/news_e/pres19_e/pr837_e.htm (дата обращения: 19.08.2019).

World Trade Organization (WTO) (2019b). World Trade Statistical Review. Режим доступа: https://www.wto. org/english/res_e/statis_e/wts2019_e/wts19_toc_e.htm (дата обращения: 21.08.2019). 